\title{
Communication
}

\section{Synthesis of trans-Mono(silyl)palladium(II) Bromide Complexes}

\author{
Melvyn B. Ansell ${ }^{1}$, George E. Kostakis ${ }^{1}\left(\mathbb{D}\right.$, Oscar Navarro ${ }^{1,2, *}$ and John Spencer ${ }^{1, *(D)}$ \\ 1 Department of Chemistry, School of Life Sciences, University of Sussex, Brighton BN1 9QJ, UK; \\ mbansel125@gmail.com (M.B.A.); G.Kostakis@sussex.ac.uk (G.E.K.) \\ 2 AMPAC Fine Chemicals, Highway 50 and Hazel Avenue, Building 05-019, \\ Rancho Cordova, CA 95741-1718, USA \\ * Correspondence: oscar.navarro@apfc.com (O.N.); j.spencer@sussex.ac.uk (J.S.); Tel.: +1-916-357-6928 (O.N.); \\ +44-1273-877-374 (J.S.)
}

\begin{abstract}
The stoichiometric reaction of $c$ is- $\left[\mathrm{Pd}(\mathrm{ITMe})_{2}\left(\mathrm{SiR}_{3}\right)_{2}\right]$, where $\left(\mathrm{SiR}_{3}=\mathrm{SiMe}_{3}\right.$ and $\mathrm{SiMe}_{2} \mathrm{Ph}$ and ITMe = 1,3,4,5-tetramethylimidazol-2-ylidene) with allyl bromide affords the corresponding allylsilanes along with complexes of the type trans-[Pd(ITMe $\left.)_{2}\left(\mathrm{SiR}_{3}\right)(\mathrm{Br})\right]$. The structure of trans$\left[\mathrm{Pd}(\mathrm{ITMe})_{2}\left(\mathrm{SiMe}_{2} \mathrm{Ph}\right) \mathrm{Br}\right] \mathbf{2} \mathbf{b}$ has been determined in the solid state and displays a slightly distorted square-planar geometry with the two N-heterocyclic carbene ligands in a trans-configuration.
\end{abstract}

Keywords: palladium; silicon; N-heterocyclic carbene; allylsilane

check for updates

Citation: Ansell, M.B.; Kostakis, G.E.; Navarro, O.; Spencer, J. Synthesis of trans-Mono(silyl)palladium(II) Bromide Complexes. Molecules 2021, 26, 2460. https://doi.org/10.3390/ molecules 26092460

Academic Editor: Vincent Ritleng

Received: 13 April 2021

Accepted: 21 April 2021

Published: 23 April 2021

Publisher's Note: MDPI stays neutral with regard to jurisdictional claims in published maps and institutional affiliations.

Copyright: (c) 2021 by the authors. Licensee MDPI, Basel, Switzerland. This article is an open access article distributed under the terms and conditions of the Creative Commons Attribution (CC BY) license (https:// creativecommons.org/licenses/by/ $4.0 /)$.

\section{Introduction}

Mono(silyl)palladium(II) halide species are purported intermediates in a number of catalytic routes towards allylsilanes [1,2]. Palladium pincer chemistry accounts of such complexes are rather numerous, although examples of their isolation in this catalytic cycle are rare [3-7]. Trans-[ $\left.\mathrm{PdCl}\left(\mathrm{SiF}_{2} \mathrm{Ph}\right)(\mathrm{L})_{2}\right]\left(\mathrm{L}=\mathrm{PMe}_{3}, \mathrm{PMe}_{2} \mathrm{Ph}\right.$ or $\left.\mathrm{PMePh}_{2}\right)$ and allyl bromide were shown to react to afford trans $-\left[\mathrm{Pd}(\mathrm{L})_{2}\left(\mathrm{SiF}_{2} \mathrm{Ph}\right)(\mathrm{Br})\right]$ and the corresponding allylsilane [1], and $\left[\left({ }^{t} \mathrm{BuPAr}_{2}\right) \mathrm{Pd}\left(\mathrm{SiMe}_{3}\right)(\mathrm{I})\right]\left(\mathrm{Ar}=3,5-\mathrm{Me}_{2}-4-\mathrm{OMe}-\mathrm{C}_{6} \mathrm{H}_{2}\right)$ was synthesized from stoichiometric quantities of [(cod) $\left.\mathrm{Pd}\left(\mathrm{CH}_{2} \mathrm{SiMe}_{3}\right)_{2}\right]$ ( $\mathrm{cod}=1,5$-cyclooctadiene), ${ }^{t} \mathrm{BuPAr}_{2}$ and $\mathrm{Me}_{3} \mathrm{SiI}$ [2]. Analogues have been used in silyl-Negishi couplings [8]. We wish to report here our preliminary findings on the reaction of (ITMe $)_{2} \mathrm{Pd}(\mathrm{silyl})_{2}$ complexes with allyl bromide (ITMe $=1,3,4,5$-tetramethylimidazol-2-ylidene) [9-12].

\section{Results and Discussion}

The bis(silyl)palladium complexes, cis-[Pd(ITMe $\left.)_{2}\left(\mathrm{SiR}_{3}\right)_{2}\right]\left(\mathbf{1 a}: \mathrm{SiR}_{3}=\mathrm{SiMe}_{3}\right.$ and $\mathbf{1 b}$ : $\mathrm{SiMe}_{2} \mathrm{Ph}[13,14]$ were reacted with excess allylbromide at room temperature under an nitrogen atmosphere to yield trans-[Pd(ITMe $\left.)_{2}\left(\mathrm{SiMe}_{3}\right)(\mathrm{Br})\right] \mathbf{2 a}$ and trans-[ $\left.\mathrm{Pd}(\mathrm{ITMe})_{2}\left(\mathrm{SiMe}_{2} \mathrm{Ph}\right) \mathrm{Br}\right]$ $\mathbf{2 b}$ in 92 and $93 \%$ yield, respectively (Scheme 1). Reaction progress was monitored by ${ }^{1} \mathrm{H}$ NMR spectroscopy. Characteristic resonances corresponding to silanes $\mathbf{3 a}$ and $\mathbf{3} \mathbf{b}$ were observed (in a 1:1 stoichiometry with $\mathbf{2} \mathbf{a} / \mathbf{2} \mathbf{b}$, respectively, upon examination of the crude mixtures).

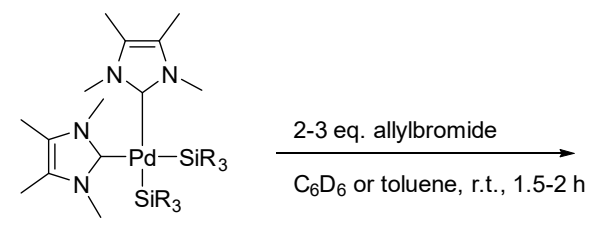

1a; $\mathrm{SiR}_{3}=\mathrm{SiMe}_{3}$

1b; $\mathrm{SiR}_{3}=\mathrm{SiMe}_{2} \mathrm{Ph}$

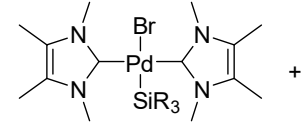

2a: $\mathrm{SiR}_{3}=\mathrm{SiMe}_{3}$ 2b : $\mathrm{SiR}_{3}=\mathrm{SiMe}_{2} \mathrm{Ph}$<smiles>[R5]CC=C</smiles>

3a: $\mathrm{SiR}_{3}=\mathrm{SiMe}_{3}$ 3b : $\mathrm{SiR}_{3}=\mathrm{SiMe}_{2} \mathrm{Ph}$
Scheme 1. Stoichiometric synthesis of mono(silyl)palladium bromide complexes. 
In order to further characterize the organometallic complexes, single crystals of $\mathbf{2} \mathbf{b}$ suitable for X-ray analysis were grown by slow evaporation of a saturated deuterated benzene solution at room temperature. $X$-ray analysis revealed that $\mathbf{2} \mathbf{b}$ displays a marginally distorted square-planar geometry with the two NHCs in a trans-configuration and orthogonal to the Br-Pd-Si plane (Figure 1, Table 1).

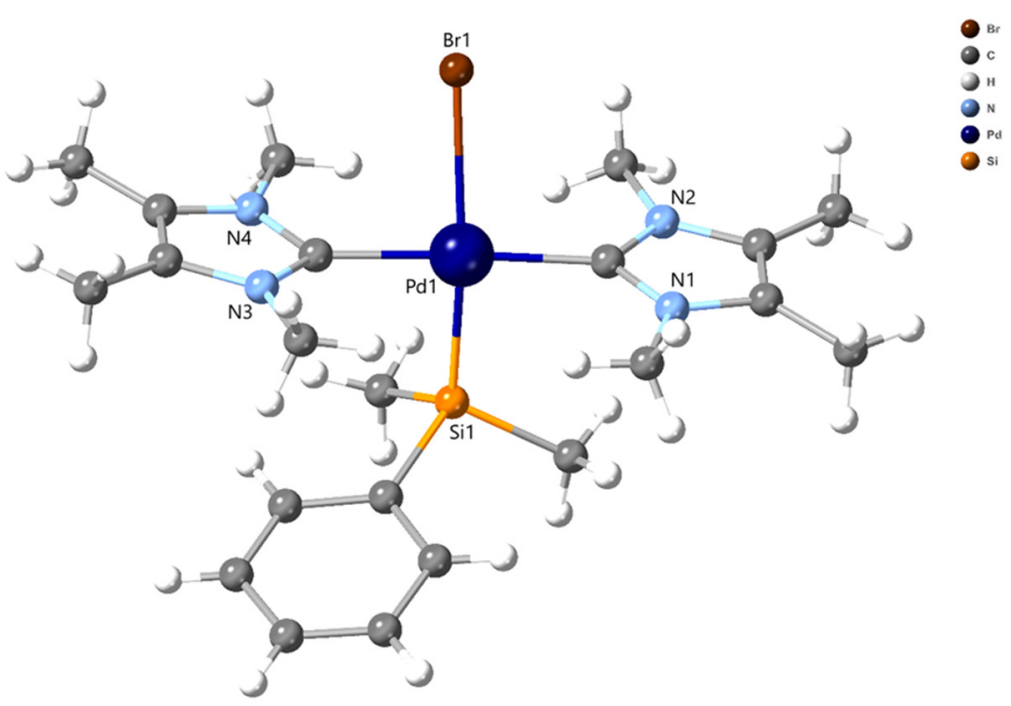

Figure 1. Molecular structure of $\mathbf{2 b}$. Hydrogen atoms are omitted for clarity. Selected bond lengths [Å] and angles [ ${ }^{\circ}$ ]: Pd1-Br1 2.6333(7), Pd-Si1 2.2948(18), Pd1-C1 2.028(5), Pd1-C8 2.025(5); C1-Pd1-Br1 94.97(16), C1-Pd1-Si1 89.15(17), C8-Pd1-Br1 87.62(16), C8-Pd1-Si1 88.60(17), C1-Pd1-C8 177.2(2).

Table 1. Crystal data and structure refinement for $\mathbf{2 b}$.

\begin{tabular}{|c|c|}
\hline Empirical formula & $\mathrm{C}_{22} \mathrm{H}_{35} \mathrm{BrN}_{4} \mathrm{PdSi}$ \\
\hline Formula weight & 569.94 \\
\hline Temperature/K & 173 \\
\hline Crystal system & orthorhombic \\
\hline Space group & $\mathrm{P} 2{ }_{1} 2_{1} 2_{1}$ \\
\hline $\mathrm{a} / \AA$ & $10.5467(4)$ \\
\hline $\mathrm{b} / \AA$ & $14.3455(3)$ \\
\hline$c / \AA$ & $16.7301(4)$ \\
\hline$\alpha /^{\circ}$ & 90 \\
\hline$\beta /{ }^{\circ}$ & 90 \\
\hline$\gamma /{ }^{\circ}$ & 90 \\
\hline Volume $/ \AA^{3}$ & 2531.23(13) \\
\hline $\mathrm{Z}$ & 4 \\
\hline$\rho_{\text {calc }} \mathrm{g} / \mathrm{cm}^{3}$ & 1.496 \\
\hline$\mu / \mathrm{mm}^{-1}$ & 2.374 \\
\hline $\mathrm{F}(000)$ & 1160.0 \\
\hline Crystal size $/ \mathrm{mm}^{3}$ & $0.22 \times 0.2 \times 0.15$ \\
\hline Radiation & $\operatorname{MoK} \alpha(\lambda=0.71073)$ \\
\hline $2 \theta$ range for data collection $/^{\circ}$ & 6.836 to 52.744 \\
\hline Index ranges & $-13 \leq \mathrm{h} \leq 8,-17 \leq \mathrm{k} \leq 11,-14 \leq 1 \leq 20$ \\
\hline Reflections collected & $\overline{7} 612$ \\
\hline Independent reflections & $4799\left[R_{\text {int }}=0.0320, R_{\text {sigma }}=0.0568\right]$ \\
\hline Data/restraints/parameters & $4799 / 0 / 272$ \\
\hline Goodness-of-fit on $\mathrm{F}^{2}$ & 1.018 \\
\hline Final $\mathrm{R}$ indexes $[\mathrm{I}>=2 \sigma(\mathrm{I})]$ & $\mathrm{R}_{1}=0.0322, \mathrm{wR}_{2}=0.0614$ \\
\hline Final $\mathrm{R}$ indexes [all data] & $\mathrm{R}_{1}=0.0376, \mathrm{w} \mathrm{R}_{2}=0.0640$ \\
\hline Largest diff. peak/hole/e $\AA^{-3}$ & $0.51 /-0.34$ \\
\hline Flack parameter & $0.004(8)$ \\
\hline CCDC deposition number & 2076437 \\
\hline
\end{tabular}


The carbenic carbon-Pd bond lengths in $\mathbf{2 b}$ [2.028(5) and 2.025(5) $\mathrm{A}]$ are significantly shorter than in cis-[Pd(ITMe $\left.)_{2}\left(\mathrm{SiMe}_{2} \mathrm{Ph}\right)_{2}\right]$ [2.105(3) and 2.123(3) $\AA$ ], suggesting $\mathrm{SiMe}_{2} \mathrm{Ph}$ exhibits a stronger trans-influence than ITMe [15]. The decreased length of the Pd-Si bond in $\mathbf{2 b}[2.2948(18) \AA]$ versus cis-[Pd(ITMe $\left.)_{2}\left(\mathrm{SiMe}_{2} \mathrm{Ph}\right)_{2}\right]$ [2.3445(8) and 2.3346(8) $\left.\mathrm{A}\right]$ infers a stronger Pd-Si bond in $\mathbf{2 b}$ and demonstrates the weak trans-influence of Br. Based on these data, the intensity of the trans-influence in these two structures follows the sequence: $\mathrm{Br}<$ ITMe $<\mathrm{SiMe}_{2} \mathrm{Ph}$. Thus, the preference for the trans-configuration observed in $\mathbf{2} \mathbf{b}$ may be attributed to the high trans-influence of $\mathrm{SiMe}_{2} \mathrm{Ph}$ and the large steric size of $\mathrm{Br}$.

A possible mechanism for the formation of 2 includes either a $\sigma$-bond metathesis between a Pd-Si, in cis-[Pd(ITMe $\left.)_{2}\left(\mathrm{SiR}_{3}\right)_{2}\right]$, and $\mathrm{Br}-\mathrm{C}$ bond, in allylbromide, or an $\mathrm{S}_{\mathrm{N}} 2 / \mathrm{S}_{\mathrm{N}} 2^{\prime}$ by the nucleophilic Pd-Si bond at the electrophilic sites in the allyl halide, leading to a trans complex. As we have previously suggested using computational studies on related bis-ITMe complexes, an NHC would then dissociate from the palladium center followed by a cis to trans isomerization of the $\mathrm{Br}$ and $\mathrm{Si}$ moieties (Scheme 2) [11]. Finally, the dissociated NHC would re-coordinate, constrained by the bulk of the other ligands, in a cis-configuration $[16,17]$.

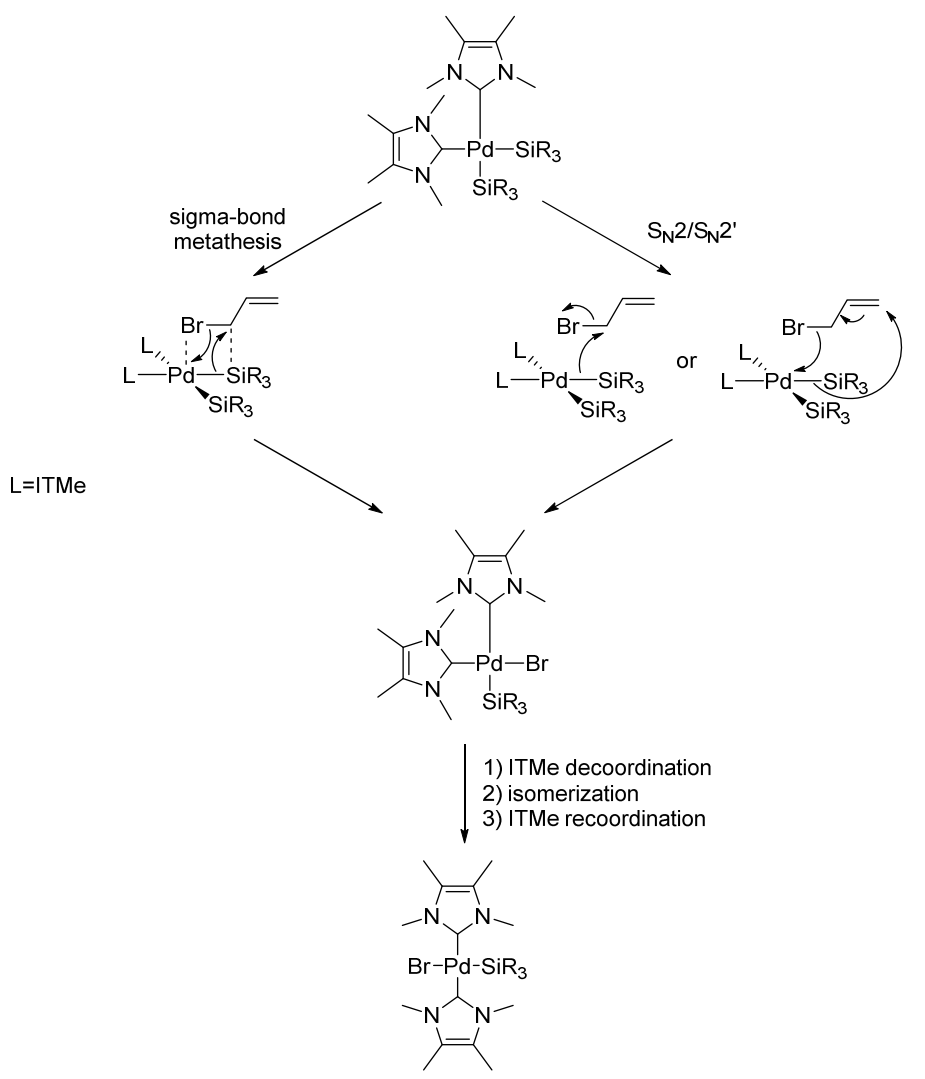

Scheme 2. Possible mechanistic routes for the formation of 2.

\section{Experimental}

The handling of air-sensitive compounds and their spectroscopic measurements were undertaken using standard Schlenk line techniques using pre-dried Ar (using a BASF R3-11(G) catalyst and $4 \AA$ molecular sieves), or in a MBraun glovebox under $\mathrm{N}_{2}$ $\left(\mathrm{O}_{2}<10.0 \mathrm{ppm}\right)$. All glassware was dried in a $160{ }^{\circ} \mathrm{C}$ oven prior to use. Celite was predried in a $200{ }^{\circ} \mathrm{C}$ oven and then dried with a heat gun under a dynamic vacuum prior to use. Filter cannulae equipped with microfiber filters were dried in an oven at $160^{\circ} \mathrm{C}$ prior to use. Solvents employed in air-sensitive reactions were dried using vacuum distillation, followed by distillation over potassium or stored over activated $4 \AA$ molecular sieves under an Ar atmosphere. NMR spectra were recorded on a Varian VNMRS 400 (Palo Alto, CA, USA) $\left({ }^{1} \mathrm{H} 399.5 \mathrm{MHz} ;{ }^{13} \mathrm{C}\{1 \mathrm{H}\} 100.5 \mathrm{MHz} ;{ }^{11} \mathrm{~B}\{1 \mathrm{H}\} 128.2 \mathrm{MHz} ;{ }^{19} \mathrm{~F} 375.9 \mathrm{MHz} ;{ }^{29} \mathrm{Si}\left\{{ }^{1} \mathrm{H}\right\}\right.$ 
$79.4 \mathrm{MHz})$, or $500\left({ }^{1} \mathrm{H} 499.9 \mathrm{MHz} ;{ }^{13} \mathrm{C}\left\{{ }^{1} \mathrm{H}\right\} 125.7 \mathrm{MHz}\right)$. Chemical shifts are reported in ppm. All other experimental details are outlined elsewhere [10].

Synthesis of trans-[Pd(ITMe $\left.)_{2}\left(\mathrm{SiMe}_{3}\right)(\mathrm{Br})\right](\mathbf{2 a})$ and Allyltrimethylsilane (3a)

Allylbromide $(0.032 \mathrm{~g}, 0.26 \mathrm{mmol})$ was added to a solution of cis-[Pd(ITMe $\left.)_{2}\left(\mathrm{SiMe}_{3}\right)_{2}\right]$ $(0.043 \mathrm{~g}, 0.09 \mathrm{mmol})$ in $\mathrm{C}_{6} \mathrm{D}_{6}$ or toluene $(3.0 \mathrm{~mL})$ and the resulting reaction mixture was stirred at room temperature for $1.5 \mathrm{~h}$. At this stage, the volatiles were removed in vacuo and the off-white powder was washed with hexane $(3 \times 4.0 \mathrm{~mL})$.

2a, Yield: $0.040 \mathrm{~g}$, 92\%. ${ }^{1} \mathrm{H}$ NMR $\left(399.5 \mathrm{MHz}, \mathrm{C}_{6} \mathrm{D}_{6}\right): \delta_{\mathrm{H}}=3.68\left[\mathrm{~s}, 12 \mathrm{H}, \mathrm{N}(1,3)-\mathrm{CH}_{3}\right]$, $1.42\left[\mathrm{~s}, 12 \mathrm{H}, \mathrm{C}(4,5)-\mathrm{CH}_{3}\right], 0.12\left[\mathrm{~s}, 9 \mathrm{H}, \mathrm{SiMe}_{3}\right] .{ }^{13} \mathrm{C}\left\{{ }^{1} \mathrm{H}\right\} \mathrm{NMR}\left(100.5 \mathrm{MHz}, \mathrm{C}_{6} \mathrm{D}_{6}\right): \delta_{\mathrm{C}}=184.9$ [NCN], $124.0\left[\mathrm{C}(4,5)-\mathrm{CH}_{3}\right], 35.1\left[\mathrm{~N}(1,3)-\mathrm{CH}_{3}\right], 8.5\left[\mathrm{C}(4,5)-\mathrm{CH}_{3}\right], 6.9\left[\mathrm{SiMe}_{3}\right] .{ }^{29} \mathrm{Si}\left\{{ }^{1} \mathrm{H}\right\} \mathrm{NMR}$ (79.4 MHz, $\mathrm{C}_{6} \mathrm{D}_{6}$ ): $\delta_{\mathrm{Si}}=7.68$. Elem. Anal. Calcd. for $\mathrm{C}_{17} \mathrm{H}_{33} \mathrm{~N}_{4} \mathrm{SiBrPd}: \mathrm{C}, 40.20 \% ; \mathrm{H}, 6.55 \%$; $\mathrm{N}, 11.03 \%$. Found: $\mathrm{C}, 40.15 \% ; \mathrm{H}, 6.54 \% ; \mathrm{N}, 10.95 \%$. 3a (from crude reaction solution), ${ }^{1} \mathrm{H}$ $\operatorname{NMR}\left(399.5 \mathrm{MHz}, \mathrm{C}_{6} \mathrm{D}_{6}\right): \delta_{\mathrm{H}}=5.77[\mathrm{~m}, 1 \mathrm{H}, \mathrm{CH}=], 4.92[\mathrm{~m}, 1 \mathrm{H}, \mathrm{CH}=], 4.89[\mathrm{~m}, 1 \mathrm{H}, \mathrm{CH}=]$, $1.44\left[\mathrm{~m}, 2 \mathrm{H}, \mathrm{CH}_{2}\right],-0.03\left[\mathrm{~s}, 9 \mathrm{H}, \mathrm{SiMe}_{3}\right]$. [Agrees with an independently taken ${ }^{1} \mathrm{H} \mathrm{NMR}$ sample of commercially available allyltrimethylsilane].

\section{Synthesis of trans-[Pd(ITMe)2(SiMe2Ph)(Br)] (2b)}

Allybromide $(6.0 \mu \mathrm{L}, 0.07 \mathrm{mmol})$ and cis-[Pd(ITMe $\left.)_{2}\left(\mathrm{SiMe}_{2} \mathrm{Ph}\right)\right](0.021 \mathrm{~g}, 0.03 \mathrm{mmol})$ were dissolved in $\mathrm{C}_{6} \mathrm{D}_{6}$ or toluene $(1.0 \mathrm{~mL})$. The resulting reaction mixture was stirred at room temperature for $2 \mathrm{~h}$ under an $\mathrm{N}_{2}$ atmosphere. At this stage, all volatiles were removed in vacuo and the resulting white solid was washed with hexane $(3 \times 2.0 \mathrm{~mL})$. Yield: $0.018 \mathrm{~g}, 93 \% .{ }^{1} \mathrm{H}$ NMR $\left(399.5 \mathrm{MHz}, \mathrm{C}_{6} \mathrm{D}_{6}\right): \delta_{\mathrm{H}}=7.20\left[\mathrm{~m}, 2 \mathrm{H}, \mathrm{SiMe}_{2} \mathrm{Ph}\right], 7.07[\mathrm{~m}$, $3 \mathrm{H}, \mathrm{SiMe}_{2} \mathrm{Ph}$ ], 3.51 [s, 12H, N(1,3)- $\mathrm{CH}_{3}$ ], 1.42 [s, 12H, C(4,5)- $\mathrm{CH}_{3}$ ], 0.31 [s, 6H, SiMe 2 Ph]. ${ }^{13} \mathrm{C}\left\{{ }^{1} \mathrm{H}\right\}$ NMR $\left(100.5 \mathrm{MHz}, \mathrm{C}_{6} \mathrm{D}_{6}\right): \delta_{\mathrm{C}}=183.4[\mathrm{NCN}], 149.6$ [SiMe $\left.\mathrm{Si}_{2}-\mathrm{Ph}\right], 133.1\left[\mathrm{SiMe}_{2} \mathrm{Ph}\right.$ ], $127.0\left[\mathrm{SiMe}_{2} \mathrm{Ph}\right], 126.5\left[\mathrm{SiMe}_{2} \boldsymbol{p}\right.$ - $\left.\mathrm{Ph}\right], 124.2\left[\mathrm{C}(4,5)-\mathrm{CH}_{3}\right], 34.9$ [N(1,3)- $\left.\mathrm{CH}_{3}\right], 8.5\left[\mathrm{C}(4,5)-\mathrm{CH}_{3}\right]$, $4.2\left[\mathrm{SiMe}_{2} \mathrm{Ph}\right] .{ }^{29} \mathrm{Si}\left\{{ }^{1} \mathrm{H}\right\} \mathrm{NMR}\left(79.4 \mathrm{MHz}, \mathrm{C}_{6} \mathrm{D}_{6}\right): \delta_{\mathrm{Si}}=2.44$. (It was not possible to obtain elemental analysis for $\mathbf{2 b}$ - every attempt resulted in numbers that were inconsistent with calculated values. A possible reason for this is decomposition of $\mathbf{2} \mathbf{b}$ by exposure to air or moisture on transit to data collection).

Crystal data for $2 \mathbf{b}: \mathrm{C}_{22} \mathrm{H}_{35} \mathrm{~N}_{4} \mathrm{SiBrPd}, M_{\mathrm{r}}=569.94 \mathrm{~g} \mathrm{~mol}^{-1}$, orthorhombic, space group $\mathrm{P} 2=22_{1}, a=10.5467(4) \AA, b=14.3455(3) \AA, c=16.7301(4) \AA, \alpha=90^{\circ}, \beta=90^{\circ}, \gamma=90^{\circ}$, $V=2531.23(13) \AA^{3}, Z=4, T=173 \mathrm{~K}, \lambda \mathrm{Mo}(\mathrm{K} \alpha)=0.71073, R_{1}[I>2 \sigma(I)]=0.0345, w R_{2}$ (all data) $=0.0677$, GooF $=1.011$.

Crude ${ }^{1} \mathrm{H}$ NMR data are consistent with the formation of allyldimethylphenylsilane $(3 \mathbf{b})$ as a product of this reaction. However, this was not isolated in this instance [18].

\section{Conclusions}

Under mild conditions, non-pincer bis(NHC)(silyl)palladium halide complexes of the type trans- $\left[\mathrm{Pd}(\mathrm{ITMe})_{2}\left(\mathrm{SiR}_{3}\right)(\mathrm{Br})\right]\left(\mathrm{SiR}_{3}=\mathrm{SiMe}_{2} \mathrm{Ph}(\mathbf{2 a})\right.$, and $\left.\mathrm{SiMe}_{3}(\mathbf{2} \mathbf{b})\right)$ were synthesized, by the reaction of allylbromide with the corresponding complexes cis-[Pd(ITMe $\left.)_{2}\left(\mathrm{SiR}_{3}\right)_{2}\right]$, $\mathbf{1 a}$ or $\mathbf{1 b}$, respectively. A possible mechanistic route for the formation of $\mathbf{2}$ involves either a $\sigma$-bond metathesis or an $S_{N} 2 / S_{N} 2^{\prime}$ reaction between allybromide and 1 . This would necessitate a cis-trans isomerization via dissociation of an NHC ligand-[19]. The reactivity of trans-[$\left[\mathrm{Pd}(\mathrm{ITMe})_{2}\left(\mathrm{SiR}_{3}\right)(\mathrm{Br})\right]$ is unexplored but will soon be carried out. The facile formation and apparent stability of trans-2 may indeed hinder the catalytic silylation of ally halides mediated by $\mathrm{ITMe}_{2} \mathrm{Pd}$-based complexes since the adoption of a cis-configuration is a prerequisite for reductive elimination and involvement in a catalytic cycle. Solutions to these unexplored questions are currently being sought, e.g., the potential for halide abstraction, and will be reported in due course.

Author Contributions: Conceptualization, M.B.A., O.N., J.S. Writing-original draft preparation, all authors; writing - review and editing, all authors. X-ray data acquisition and refinement: M.B.A. and G.E.K. All authors have read and agreed to the published version of the manuscript. 
Funding: This research was funded by an EPSRC Standard Research Studentship (DTG, Grant \# EP/L505109/1), to M.B.A.

Institutional Review Board Statement: Not applicable.

Acknowledgments: Dedicated to Michel Pfeffer for his contributions to C-H activation, palladium, and ruthenium chemistry. A gentleman and a scholar.

Conflicts of Interest: The authors declare no conflict of interest.

Sample Availability: No samples of the compounds are available from the authors.

Disclosure: This work has been previously presented as part of a thesis available at: Ansell, Melvyn B (2017) Novel (N-heterocyclic carbene)-palladium(0) complexes as catalysts in element-element bond additions to unsaturated moieties. Doctoral thesis (PhD), University of Sussex, Brighton BN1 9QJ, UK; http: //sro.sussex.ac.uk/id/eprint/68072/, accessed on 12 May 2017).

\section{References}

1. Ozawa, F.; Sugawara, M.; Hasebe, K.; Hayashi, T. Reactions of bis(silyl)palladium(II) complexes with allyl halides. Synthesis of mono(silyl)palladium(II) halides and X-ray structure of trans-PdCl(SiF2Ph)(PMe2Ph)2. Inorg. Chim. Acta 1999, 296, 19-25. [CrossRef]

2. McAtee, J.R.; Yap, G.P.A.; Watson, D.A. Rational design of a second generation catalyst for preparation of allylsilanes using the silyl-Heck reaction. J. Am. Chem. Soc. 2014, 136, 10166-10172. [CrossRef] [PubMed]

3. MacInnis, M.C.; MacLean, D.F.; Lundgren, R.J.; Mcdonald, R.; Turculet, L. Synthesis and reactivity of platinum group metal complexes featuring the new pincer-like bis (phosphino) silyl ligand [K3-(2-Ph 2PC6H4)2SiMe]-([PSiP]): Application in the ruthenium-mediated transfer hydrogenation of ketones. Organometallics 2007, 26, 6522-6525. [CrossRef]

4. Takaya, J.; Nakamura, S.; Iwasawa, N. Synthesis, structure, and catalytic activity of palladium complexes bearing a tridentate pxp-pincer ligand of heavier group 14 element $(X .=$ Ge, Sn). Chem. Lett. 2012, 41, 967-969. [CrossRef]

5. Ruddy, A.J.; Mitton, S.J.; Mcdonald, R.; Turculet, L. Hemilabile' silyl pincer ligation: Platinum group PSiN complexes and triple C-H activation to form a (PSiC)Ru carbene complex. Chem. Commun. 2012, 48, 1159-1161. [CrossRef]

6. Wahlicht, S.; Brendler, E.; Heine, T.; Zhechkov, L.; Wagler, J. 7-Azaindol-1-yl(organo)silanes and Their PdCl ${ }_{2}$ Complexes: PdCapped Tetrahedral Silicon Coordination Spheres and Paddlewheels with a Pd-Si Axis. Organometallics 2014, 33, $2479-2488$. [CrossRef]

7. Suh, H.W.; Balcells, D.; Edwards, A.J.; Guard, L.M.; Hazari, N.; Mader, E.A.; Mercado, B.Q.; Repisky, M. Understanding the Solution and Solid-State Structures of Pd and Pt PSiP Pincer-Supported Hydrides. Inorg. Chem. 2015, 54, 11411-11422. [CrossRef] [PubMed]

8. Cinderella, A.P.; Vulovic, B.; Watson, D.A. Palladium-Catalyzed Cross-Coupling of Silyl Electrophiles with Alkylzinc Halides: A Silyl-Negishi Reaction. J. Am. Chem. Soc. 2017, 139, 7741-7744. [CrossRef] [PubMed]

9. Ansell, M.B.; Furfari, S.K.; Cloke, F.G.N.; Roe, S.M.; Spencer, J.; Navarro, O. Comparison of the Reactivity of the Low Buried-Volume Carbene Complexes (ITMe)2Pd(PhC $\equiv \mathrm{CPh})$ and (ITMe)2Pd(PhN=NPh). Organometallics 2018, 37, 1214-1218. [CrossRef]

10. Ansell, M.B.; Menezes Da Silva, V.H.; Heerdt, G.; Braga, A.A.C.; Spencer, J.; Navarro, O. An experimental and theoretical study into the facile, homogenous (N-heterocyclic carbene)2-Pd(0) catalyzed diboration of internal and terminal alkynes. Catal. Sci. Technol. 2016, 6, 7461-7467. [CrossRef]

11. Ansell, M.B.; Kostakis, G.E.; Braunschweig, H.; Navarro, O.; Spencer, J. Synthesis of Functionalized Hydrazines: Facile Homogeneous (N-Heterocyclic Carbene)-Palladium(0)-Catalyzed Diboration and Silaboration of Azobenzenes. Adv. Synth. Catal. 2016, 358. [CrossRef] [PubMed]

12. Ansell, M.B.; Navarro, O.; Spencer, J. Transition metal catalyzed element-element' additions to alkynes. Coord. Chem. Rev. 2017, 336. [CrossRef]

13. Ansell, M.B.; Roberts, D.E.; Cloke, F.G.N.; Navarro, O.; Spencer, J. Synthesis of an [(NHC)2Pd(SiMe3)2] complex and catalytic cis-bis(silyl)ations of alkynes with unactivated disilanes. Angew. Chem. Int. Ed. 2015, 54, 5579-5582. [CrossRef] [PubMed]

14. Ansell, M.B.; Spencer, J.; Navarro, O. (N-Heterocyclic Carbene)2-Pd(0)-Catalyzed Silaboration of Internal and Terminal Alkynes: Scope and Mechanistic Studies. ACS Catal. 2016, 6, 2192-2196. [CrossRef]

15. Mo, Z.; Liu, Y.; Deng, L. Anchoring of silyl donors on a N-heterocyclic carbene through the cobalt-mediated silylation of benzylic C-H bonds. Angew. Chem. Int. Ed. 2013, 52, 10845-10849. [CrossRef] [PubMed]

16. De, K.; Lewis, A.K.; Caddick, S.; Cloke, F.G.N.; Billingham, N.C.; Hitchcock, P.B.; Leonard, J. Synthetic, structural, and mechanistic studies on the oxidative addition of aromatic chlorides to a palladium (N-heterocyclic carbene) complex: Relevance to catalytic amination. J. Am. Chem. Soc. 2003, 125, 10066-10073.

17. De, K.; Lewis, A.K.; Caddick, S.; Esposito, O.; Cloke, F.G.N.; Hitchcock, P.B. Synthetic and structural studies on amine coordination to Pd-N-heterocyclic carbene complexes. Dalt. Trans. 2009, 35, 7094-7098. 
18. Godineau, E.; Schenk, K.; Landais, Y. Synthesis of fused piperidinones through free-radical-ionic cascade. J. Org. Chem. 2008, 73, 6983-6993. [CrossRef] [PubMed]

19. Suarez, A.G.; Nelson, D.J.; Nolan, S.P. Quantifying and understanding the steric properties of N-heterocyclic carbens. Chem. Commun. 2017, 53, 2650-2660. [CrossRef] [PubMed] 